\author{
Brigita Žuromskaitè \\ ORCID 0000-0002-6837-344X \\ Uniwersytet Michała Romera w Wilnie \\ Wydział Zarządzania Publicznego \\ Instytut Zarządzania \\ brigitaz@mruni.eu \\ Rafał Nagaj \\ ORCID 0000-0002-9410-7663 \\ Uniwersytet Szczeciński \\ Wydział Nauk Ekonomicznych i Zarządzania \\ Instytut Ekonomii \\ rafal.nagaj@usz.edu.pl
}

\title{
OBIEKTY TURYSTYKI KULTUROWEJ W KONTEKŚCIE ZWIĘKSZONEGO RYZYKA TERRORYSTYCZNEGO: MŁODZI TURYŚCI Z LITWY WOBEC ŚRODKÓW BEZPIECZEŃSTWA
}

\begin{abstract}
Abstrakt: Ataki terrorystyczne w popularnych destynacjach turystycznych spowodowały pojawienie się istotnego dylematu, jakim jest znalezienie sposobów ochrony turystów i zapewnienie im odpowiedniej jakości odpoczynku. W artykule została przeprowadzona analiza ważności „miękkich” i „twardych” środków bezpieczeństwa, stosowanych w obiektach turystyki kulturowej, na podstawie przeprowadzonych wśród młodych turystów z Litwy badań ankietowych. Ich wyniki pokazały, że młodzi turyści znają środki bezpieczeństwa, stosowane w miejscach zagrożenia terroryzmem, chcą jednak podróżować bez ograniczeń, w poczuciu wolności, ale także z pewnością, że podróżują bezpiecznie.
\end{abstract}

Słowa kluczowe: infrastruktura turystyczna, ryzyko terrorystyczne, bezpieczeństwo turystów.

\section{WPROWADZENIE}

Występujące w ostatnich dwóch dekadach XXI w. liczne akty terroryzmu na świecie spowodowały, że temat bezpieczeństwa $w$ turystyce jest coraz częściej poruszany $\mathrm{w}$ badaniach naukowych. Ataki terrorystyczne z września 2001 r. miały znaczący wpływ na zmianę postrzegania bezpieczeństwa $\mathrm{w}$ turystyce i wśród turystów (TARLOW 2014). Jak zauważyli S. HORNER i J. SWARBROOKE (2009), w XXI w. to właśnie turyści stają się często jednym $\mathrm{z}$ głównych celów terrorystów. Przyczyną jest fakt, że są oni łatwo rozpoznawalni (wyróżniają się wyglądem i sposobem bycia) i przez to bywają narażeni na wszelkiego rodzaju ataki terrorystyczne czy sytuacje zagrażające ich życiu. Zdaniem P. TARLOWA (2006) sektor turystyczny powinien adaptować się do nowych warunków, być gotowy na tego typu wyzwania i wkładać maksymalnie dużo wysiłku w chronę turystów przed potencjalnymi zagrożeniami.

Miejscem, w którym turyści mogą być narażeni na ataki terrorystyczne jest infrastruktura turystyczna, czyli baza noclegowa i gastronomiczna oraz popularne atrakcje/obiekty turystyczne. Jak wynika z literatury, ataki są coraz częściej dokonywane w popularnych destynacjach turystycznych (głównie w obiektach infrastruktury turystycznej, takich jak: hotele, restauracje, dworce, obiekty turystyki kulturowej), które są licznie odwiedzane przez turystów z całego świata (PACZYŃSKA-JĘDRYCKA, EIDER 2017).

Powstaje pytanie, w jaki sposób ochronić turystów przed potencjalnym niebezpieczeństwem, a jednocześnie nie pogorszyć komfortu ich wypoczynku i nie ograniczyć ich przestrzeni osobistej. Rozwiązanie tak określonego problemu badawczego zostało zaproponowane w niniejszym artykule. Celem autorów pracy jest identyfikacja środków bezpieczeństwa stosowanych $\mathrm{w}$ infrastrukturze turystyki kulturowej oraz ocena stopnia ich ważności dokonana przez młodych turystów z Litwy. Realizacji tego celu służy przegląd literatury przedmiotu oraz analiza wyników badań ankietowych. Podmiotem badania są ludzie młodzi 
- grupa osób urodzonych po 1980 r. - które chętnie inwestują swoje pieniądze i czas w podróże (MOISĂ 2010). Jak wskazują przeprowadzone studia literatury, często wybierają one nowe destynacje turystyczne oraz dłuższe podróże (How Millennials killed travel...). Ponadto są bardziej otwarte, niż starsze generacje społeczeństw, na nowe doznania, śledzenie tradycji, kultury, a także na poznawanie nowych ludzi (BUFFA 2015, MORRISON i in. 2016). Należy jednak zaznaczyć, że młodzi turyści są jednocześnie mniej ostrożni niż starsi, chętnie dzielą się informacją, nieraz o charakterze osobistym, na różnego rodzaju stronach internetowych czy w portalach społecznościowych (BARTON i in. 2013). Starsi turyści, gdy usłyszą o zwiększonym zagrożeniu w miejscu docelowym ich podróży, zazwyczaj odstępują od wyjazdu (GARG 2015). Młodzi tymczasem nie są zbyt chętni, aby szybko rezygnować $\mathrm{z}$ obranego celu turystycznego (MACHADO 2014). Jednak, jak zaznacza P. MURA (2010), część z nich to osoby „odważne” tylko do pewnego stopnia zagrożenia.

Przedstawione powyżej fakty sprawiają, że opinia młodych turystów z Litwy o środkach bezpieczeństwa stosowanych w infrastrukturze turystyki kulturowej jest ważna i może dostarczać wartościowej, nie tylko naukowo, informacji. Fakt natomiast, że owa problematyka nie była podejmowana $\mathrm{w}$ odniesieniu do tej grupy demograficznej z Litwy, w kontekście nowych zagrożeń, z jakimi zmaga się sektor turystyczny na świecie, może stanowić cenny wkład do szeroko zakrojonych badań nad tą tematyką.

\section{TERRORYZM A TURYSTYKA}

Warunkiem niezbędnym do rozwoju turystyki w regionie jest zarówno dobra sytuacja polityczna, jak i ekonomiczna (MANSFELD, PIZAM 2006). Nie mniejsze znaczenie ma także poziom bezpieczeństwa turystów, a mianowicie: ochrona ich życia, zdrowia i majątku (BERNAŚ, PUJER 2014). Jego istotność wynika również z faktu, że wpływa na sposób postrzegania sektora turystycznego i destynacji turystycznych przez podróżujących. Warto zwrócić uwage na to, że w ostatnich latach jest obserwowana wśród turystów zmiana poglądu na temat znaczenia bezpieczeństwa podczas podróży. Skutkuje to wyborem przez część z nich bezpiecznych regionów turystycznych, tzn. takich, w których w infrastrukturze turystycznej są zapewnione wszelkiego rodzaju środki bezpieczeństwa i nie odnotowuje się wśród turystów zwiększonej liczby zgonów (SURVILA, MiKĖNAS, ŽUROMSKAITE் 2017). Wyniki badań, prezentowane w literaturze (HORNER, SWARBROOKE 2009), pozwalają na stwierdzenie, że w regionach turystycznych, w których miały miejsce ataki terrorystyczne, zauważalny jest spadek liczby osób odwiedzających. Ujemny wpływ zagrożenia terrorystycznego na sektor turystyczny potwierdzają międzynarodowe badania empiryczne przeprowadzone w 2016 i 2017 r. przez International SOS i Ipsos Mori (Travel risk... b.r.w.). Zgodnie z nimi w 2016 r. aż 80\% badanych udzieliło odpowiedzi, że decydując się na wyjazd, musiało zmienić wcześniej obrany kierunek podróży, a 51\% stwierdziło, że głównym powodem zmiany było zagrożenie terrorystyczne (Travel risk... b.r.w.). Można zatem wysunąć tezę, że turyści są wrażliwi na stan bezpieczeństwa i w sytuacji wysokiego zagrożenia terrorystycznego rezygnują $z$ wyjazdów do miejsc obarczonych takim ryzykiem.

Jak widać, ataki i już nawet zagrożenie terrorystyczne bezpośrednio wpływają na turystykę (ŽUROMSKAITĖ, NAGAJ, DAČIULYTĖ 2018). Im więcej takich zagrożeń występuje na danym terenie, tym większe prawdopodobieństwo, że straci on na popularności wśród turystów, co oczywiście będzie skutkowało obniżeniem dochodów z tego sektora. Wspomniane zagrożenie może mieć negatywny wpływ na rozwój sektora turystycznego zarówno na poziomie lokalnym, regionalnym, jak i międzynarodowym (SANTANA 2005).

Ataki terrorystyczne w popularnych miejscach turystycznych wzbudzają wielkie zainteresowanie prasy na całym świecie. Media odgrywają nie tylko rolę źródła informacji o bieżących wydarzeniach, ale kształtują także wiedzę turystów o regionach turystycznych. Wybierając potencjalny kierunek podróży, dzięki informacjom $\mathrm{z}$ mediów, turyści mają już podstawową wiedzę i wyrobioną opinię na temat stanu bezpieczeństwa $\mathrm{w}$ tym regionie turystycznym (SCHROEDER, PENNINGTON-GRAY, KAPLANIDOU, ZHAN 2013). Jednak warto wziąć pod uwagę fakt, że media, w pogoni za sensacją, czasami wzbudzają dodatkowe emocje, wywołując nadmierny strach wśród turystów. Dzieje się to $\mathrm{w}$ wyniku publikowania zbyt szybko nie do końca zweryfikowanych informacji, które mogą być tylko pogłoskami lub półprawdami. Wpływają one jednak na kształtowanie się negatywnego wizerunku danej destynacji turystycznej, który może znacznie różnić się od rzeczywistej sytuacji w niej.

Oczywiście media nie są jedynym źródłem informacji na temat stopnia ryzyka wyjazdu do określonego ośrodka turystycznego. Warto korzystać z informacji na stronach rządowych, opinii ekspertów ds. turystyki czy pracowników biur podróży, ale także wysłuchać opinii bliskich nam osób (rodzina i przyjaciele) (ŽUROMSKAITÉ, NAGAJ, DAČIULYTĖ 2018).

Analizując zależności między terroryzmem a turystyką, można zauważyć, że wśród turystów często pojawia się tzw. efekt zakotwiczenia (ang. anchoring 


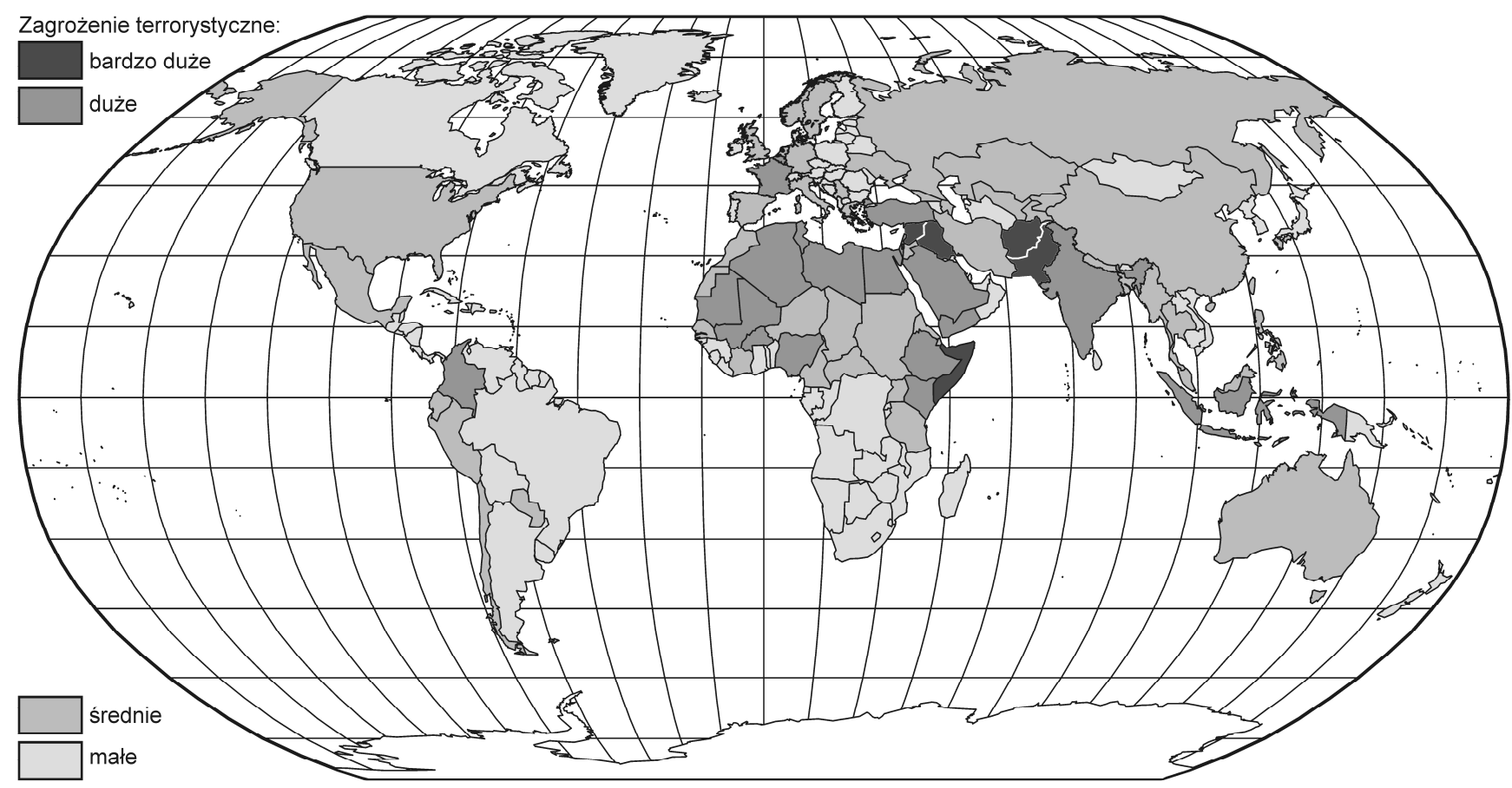

Rys. 1. Mapa zagrożenia terrorystycznego na świecie

Źródło: red24's Global Terrorism Risk Map 2017

bias), co oznacza, że podejmując decyzję dotyczącą destynacji turystycznej opierają się oni na nieistotnych zapamiętanych informacjach. Odnośnie do wybranego regionu geograficznego może natomiast wystąpić tzw. efekt generalizacji (ang. generalization effect), powstający wówczas, gdy wydarzenia w danym ośrodku turystycznym skutkują złą opinią na temat całego regionu lub kraju, mimo faktu, że w innych ośrodkach tego regionu takie zagrożenia mogą nie mieć miejsca lub występują na znacznie mniejszą skalę. Przyczyną takich zjawisk są zarówno czynniki subiektywne, jak i obiektywne. Pierwsze $z$ nich to uleganie przez podróżujących "zniekształceniom poznawczym" i emocjom. Drugie wynikają z tego, że stosunkowo łatwo można uczynić turystów celem ataku terrorystycznego. Łatwo jest ich bowiem zidentyfikować (inny wygląd, inny styl ubierania się i sposób zachowania) oraz określić miejsca ich najczęstszego pobytu (głównie spędzają czas w infrastrukturze turystycznej) (MARCZAK 2012). Niebagatelnym czynnikiem jest także fakt, że w atakach terrorystycznych często giną obywatele różnych narodowości, co wzbudza większe zainteresowanie mediów w wielu krajach i tym samym umożliwia terrorystom realizację celu ich działań, jakim jest szerokie nagłośnienie tego, co robią.
Wymiernym negatywnym skutkiem wzrostu zagrożenia atakami terrorystycznymi w destynacjach turystycznych jest spadek zainteresowania tymi kierunkami wyjazdów turystycznych i znaczne zmniejszenie liczby turystów tam podróżujących. To przekłada się automatycznie na zmniejszone dochody $z$ turystyki oraz wynikające $z$ tego kolejne negatywne skutki ekonomiczne (np. upadające przedsiębiorstwa i wzrost bezrobocia w sektorze turystycznym, a w skali kraju - zmniejszone tempo wzrostu PKB), o których będzie mowa w rozdziale 3 .

Na rys. 1 przedstawiono kształtowanie się stopnia zagrożenia terrorystycznego na świecie. Mapa pokazuje, że największe zagrożenie występuje w regionach okołorównikowych, tj. w Afryce Północnej, na Bliskim Wschodzie, w Południowej Azji oraz Oceanii. Warto zwrócić uwagę, że są to najczęściej regiony popularne turystycznie bądź stanowiące potencjalną destynację turystyczną. Litwa, z której młodzi turyści podlegali w niniejszym artykule badaniu, należy do krajów o niskim poziomie zagrożenia. Fakt ten może sprawiać, że podróżujący Litwini mogą mieć zniekształcone pojęcie na temat własnego bezpieczeństwa czy potencjalnych zagrożeń w odwiedzanych przez nich miejscach. 


\section{EKONOMICZNE SKUTKI ATAKÓW TERRORYSTYCZNYCH W SEKTORZE TURYSTYCZNYM}

Ataki terrorystyczne mają wpływ nie tylko na podjęcie decyzji o podróżowaniu, ale także na sposób postrzegania danej destynacji turystycznej. Oddziałują też niekiedy w znacznym stopniu na kondycję ekonomiczną sektora turystycznego. Przykładem takiego oddziaływania jest tragiczne wydarzenie z 11 września 2001 r. w Nowym Jorku (HORNER, SWARBROOKE 2009), które spowodowało w Stanach Zjednoczonych znaczne straty ekonomiczne $w$ różnych gałęziach usługowych: w liniach lotniczych, bazie noclegowej i gastronomicznej oraz innych przedsiębiorstwach kooperujących z sektorem turystycznym. Co ciekawe, mimo że głównym celem tego ataku nie byli turyści, to właśnie ten sektor poniósł największe straty ekonomiczne. W ciągu pierwszego miesiąca po ataku terrorystycznym przychody sektora turystycznego w Stanach Zjednoczonych zmniejszyły się o 33\%, linie lotnicze straciły blisko $50 \%$ pasażerów, zostało odwołanych około 25\% konferencji oraz innych spotkań na wysokim szczeblu, a przedsiębiorstwa turystyczne tylko w ciagu jednego dnia poniosły straty w wysokości 51 mln USD (HORNER, SWARBROOKE 2009). Ponadto $\mathrm{w}$ gospodarce USA PKB zmniejszyło się o 1,8\%, a 1,1 mln osób straciło pracę. Z powodu wystąpienia efektu generalizacji, skutek ekonomiczny tej tragedii dotyczył nie tylko miejsc samych ataków terrorystycznych, ale także regionów kojarzonych ze Stanami Zjednoczonymi. Przykładem są choćby Karaiby, które w tym czasie odwiedziło o 13,5\% mniej turystów oraz gdzie zostało zwolnionych około 365 tys. pracowników. Także strategiczny partner USA - Wielka Brytania - w ciągu trzech miesięcy stracił 16 mln funtów (HORNER, SWARBROOKE 2009).

Z przestudiowanej literatury wynika, że przedstawiciele infrastruktury turystycznej, reagując na zmieniające się zachowania turystów, podejmują działania mające na celu zmniejszenie potencjalnego ryzyka niebezpiecznej podróży dla turysty, by ochronić go, a także zminimalizować obniżenie komfortu wypoczynku wynikające z tych działań (SURVILA, MIKĖ-NAS, ŽUROMSKAITE 2017). Zaczęły być powszechnie stosowane różne środki bezpieczeństwa w bazie noclegowej, m.in.: skanowanie bagażów gości, kontrola transportu przybywającego do obiektu i jego skanowanie, wykorzystywanie wykrywaczy metalu przy wejściach do obiektu, montowanie szyb kuloodpornych, wyposażanie budynków w monitoring/kamery oraz zatrudnianie całodobowej ochrony obiektu - uzbrojonych ochroniarzy (HENDERSON 2007). W obiektach infrastruktury turystyki kulturowej są natomiast stosowane takie środki bezpieczeństwa, jak: dodatkowe kamery, policja turystyczna, wykrywacze metalu przy wejściach do obiektu, a także sprawdzanie rzeczy osobistych turystów przy wejściach do obiektu. To wszystko wiąże się z koniecznością zwiększenia nakładów inwestycyjnych, które sektor turystyczny musiał i musi obecnie ponosić w celu podniesienia poziomu bezpieczeństwa.

Oczywiście to niejedyne działania podejmowane (lub które mogą być podejmowane) przez przedstawicieli sektora turystycznego i przedsiębiorstw $\mathrm{z}$ nim współpracujących, w związku ze wzrostem zagrożenia terrorystycznego $\mathrm{w}$ destynacjach turystycznych. Stosowane są również takie, które wywołują negatywne skutki ekonomiczne, jak np.: zmniejszanie zatrudnienia czy inwestycji $\mathrm{w}$ sektorze turystycznym lub rezygnacja $\mathrm{z}$ organizacji wycieczek do niebezpiecznych miejsc turystycznych (HORNER, SWARBROOKE 2009, SANTANA 2005). Przykładowo, linie lotnicze, obsługujące loty do niebezpiecznych miejsc czy krajów, mogą zrezygnować z wielkich samolotów i zastąpić je małymi, ale także zmniejszyć liczbę pracowników pokładowych. Biura turystyczne natomiast mogą zaprzestać sprzedaży podróży do niebezpiecznych lokalizacji z powodu zagrożenia terroryzmem regionów turystycznych lub ich wybranych części.

Trudno nawet oszacować wszystkie skutki ekonomiczne wzrostu zagrożenia terrorystycznego. Jednak, jak twierdzi P. TARLOW (2006), bezpieczeństwo turystów powinno być priorytetem dla całego sektora turystycznego. Powstaje zatem pytanie: czy wszystkie zastosowane środki bezpieczeństwa przyniosą oczekiwane efekty i czy nie będą miały negatywnego wpływu na jakość odpoczynku w wybranym przez podróżującego regionie turystycznym.

\section{PRZEBIEG BADAŃ ORAZ CHARAKTERYSTYKA RESPONDENTÓW}

Jak już stwierdzono, zamierzeniem autorów niniejszej pracy jest identyfikacja środków bezpieczeństwa stosowanych w infrastrukturze turystyki kulturowej oraz ocena ich ważności, dokonana przez młodych turystów z Litwy. Realizacji tego celu służył przegląd literatury przedmiotu oraz sondaż diagnostyczny. Analizę literatury wykorzystano do identyfikacji środków bezpieczeństwa, które były następnie przedmiotem oceny przez ankietowanych i przeprowadzonej przez autorów analizy empirycznej. W ramach sondażu diagnostycznego wykorzystano narzędzie badania ankietowego, na które składały się: siedem pytań kwestionariusza osobowego, cztery pytania charakteryzujące preferencje turystyczne badanych oraz osiem pytań ankietowych, na które odpowiedzi pozwolity ocenić stosunek turystów do bezpieczeństwa podró- 
żowania. W badaniu ankietowym ocenie poddano środki bezpieczeństwa wyodrębnione przez J.C. HENDERSONA (2007) oraz przez autorów artykułu, kierujących się obserwacją własną w popularnych obiektach turystyki kulturowej. W celu poznania opinii młodych turystów z Litwy na temat środków bezpieczeństwa stosowanych w infrastrukturze turystyki kulturowej i oceny ich istotności, w okresie styczeń-maj 2018 r., zostały przeprowadzone badania ankietowe.

$\mathrm{W}$ ankiecie respondenci, stosując skalę Likerta (od 1 - nieistotne, niepotrzebne, do 5 - bardzo ważne, potrzebne), oceniali główne środki bezpieczeństwa stosowane $\mathrm{w}$ infrastrukturze turystyki kulturowej. W artykule wykorzystano do dalszych analiz odpowiedzi na następujące pytanie: "Jakie środki bezpieczeństwa w atrakcjach/obiektach turystycznych są dla Państwa ważne i poprawiałyby jakość Państwa wypoczynku?". Ankietowani musieli ocenić następujące środki bezpieczeństwa: patrolujący wojskowi, dodatkowe kamery, dyżurujące służby pogotowia ratunkowego w obiekcie, policja turystyczna, wykrywacze metalu przy wejściach do obiektu, sprawdzanie rzeczy osobistych turystów przy wejściach do obiektu, weryfikacja dokumentów, ogrodzony teren obiektu turystycznego i jego ochrona, ulotki informacyjne na temat potencjalnych zagrożeń oraz informacje o zagrożeniach.

Badaniu - jak wcześniej pisano - zostali poddani młodzi turyści litewscy (badania przeprowadzono na Wydziale Zarządzania Publicznego w Uniwersytecie Michała Romera w Wilnie), a liczebność próby ogółem wyniosła $\mathrm{N}=358$ (51,1\% ogółu studiujących). Większość ankietowanych miało 20-29 lat. W wieku 20-24 lat było 47\% studentów, natomiast 25-29 lat - 29\%, resztę stanowiły osoby młodsze lub starsze. Wśród respondentów więcej - 76,5\% - było kobiet, a tylko 23,5\% mężczyzn. Osoby pozostające w stałym związku stanowiły 70\%, nieposiadające dzieci $78 \%$. Oceniając aktywność zawodową ankietowanych, zidentyfikowano $71 \%$ osób pracujących i $29 \%$ uczących się (studentów).

W badaniu wzięto pod uwagę tylko osoby odbywające co najmniej raz w roku podróż turystyczną. Większość stanowili respondenci często podróżujący, spośród których $42 \%$ wyjeżdżało dwa-trzy razy w roku, 13\% - cztery-siedem razy w roku, a 5,3\% - osiem lub więcej razy. Jedynie $28 \%$ ankietowanych podejmowało wyjazdy turystyczne tylko jeden raz w roku. Poddana badaniu grupa turystów z Litwy najczęściej podróżowała w celach poznawczych $(21,7 \%)$ oraz wypoczynkowych (24,7\%) (rys. 2).

Analiza kierunku podróżowania wykazała, że litewscy młodzi turyści jako cel swoich wyjazdów najczęściej wybierali kraje europejskie (48\%) oraz Litwę (38,3\%). Niewielki odsetek podróżujących (ok. 5,5\%) odwiedzał natomiast regiony turystyczne o podwyższonym ryzyku podróżowania lub zaliczane do nie- bezpiecznych (rys. 3). Warto tu wspomnieć, że znaczna część ankietowanych turystów wybierała państwa Europy Zachodniej, wśród których są także te o podwyższonym ryzyku ataków terrorystycznych.

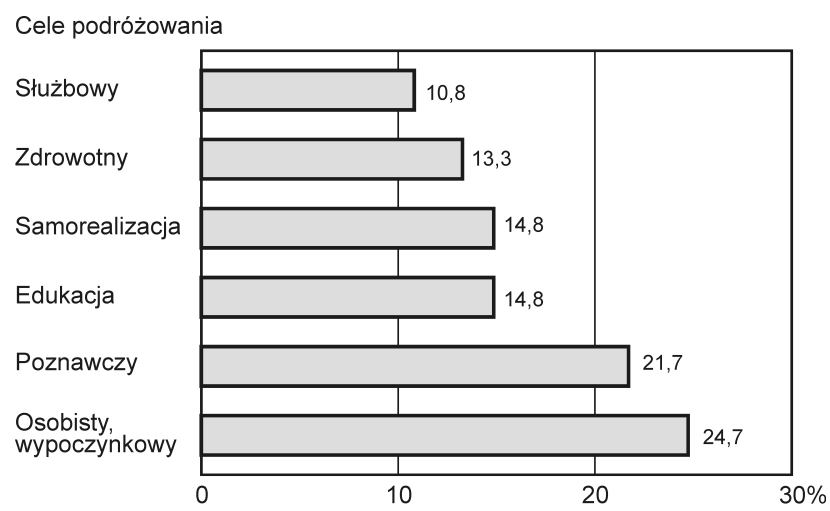

Rys. 2. Cele podróżowania badanych młodych Litwinów w pierwszej połowie $2018 \mathrm{r}$. Źródło: opracowanie własne

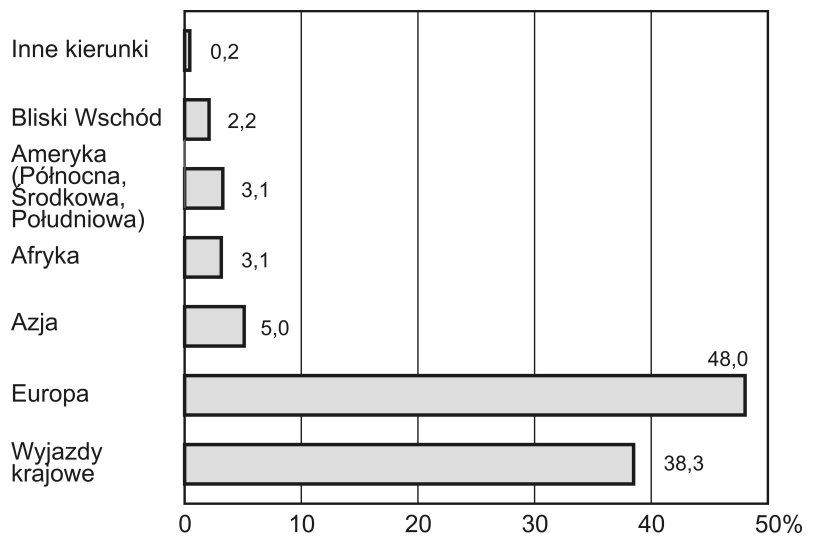

Rys. 3. Główne kierunki podróżowania badanych młodych Litwinów w pierwszej połowie $2018 \mathrm{r}$. Źródło: opracowanie własne

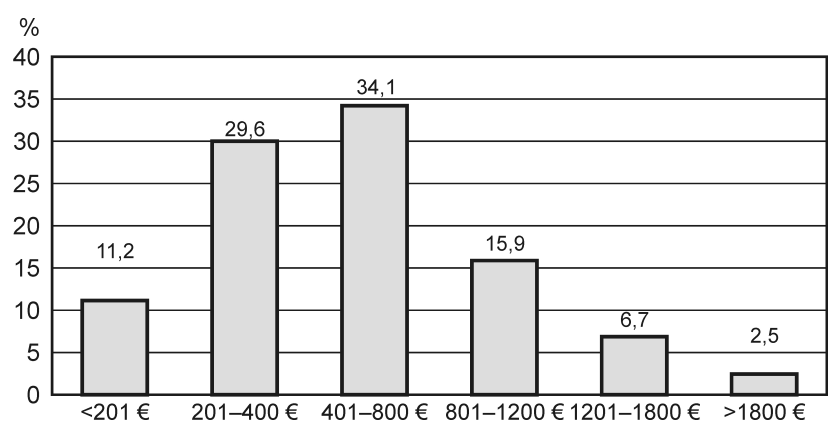

Rys. 4. Całkowity budżet przeznaczony na podróż turystyczną na 1 osobę przez badanych młodych Litwinów w pierwszej połowie $2018 \mathrm{r}$.

Źródło: opracowanie własne

Respondentów pogrupowano także według wielkości średniego poziomu wydatków ponoszonych na wyjazd turystyczny (rys. 4). Uzyskane rezultaty badań 
pokazały, że ankietowani najczęściej na swoją podróż wydają powyżej 200 euro (201-400 euro 29,6\% i 401800 euro $34,1 \%$ ).

Wynika z tego, że młodzi mieszkańcy Litwy (poddani badaniu) nie wydawali dużych kwot na wyjazdy turystyczne. Są bardziej zainteresowani tym, by odbyć podróż i zobaczyć jak najwięcej, niż by inwestować w jakość podróży i wypoczynku, tzn. w infrastrukturę turystyczną (wybierają tanie linie lotnicze, bazę noclegową o niższym standardzie).

\section{5. ŚRODKI BEZPIECZEŃSTWA W INFRASTRUKTURZE TURYSTYKI KULTUROWEJ}

Określając na początku artykułu cel jego autorów, stwierdzono, że stanowiła go ocena głównych środków bezpieczeństwa stosowanych w infrastrukturze turystyki kulturowej. Przeprowadzone badania ankietowe pozwoliły stwierdzić, że respondenci w podobny sposób oceniają wszystkie spotykane w obiektach turystycznych środki bezpieczeństwa, tzn. co najmniej połowa ankietowanych oceniła niemal każdy z nich jako ważny i potrzebny lub bardzo ważny i niezbędny, co można zaobserwować, analizując rys. 5 .

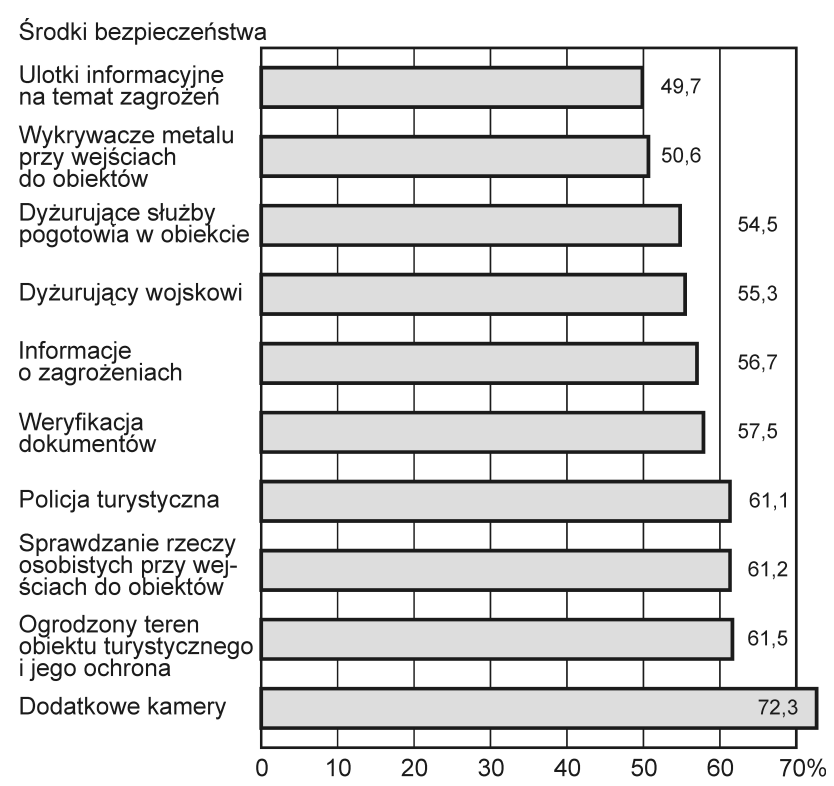

Rys. 5. Środki bezpieczeństwa, które poprawiają jakość wypoczynku respondentów w atrakcjach/obiektach turystycznych z Litwy w pierwszej połowie 2018 r. (są ważne i bardzo ważne) Źródło: opracowanie własne

Środkiem bezpieczeństwa, który młodzi turyści z Litwy uważają za najważniejszy w infrastrukturze turystyki kulturowej, jest występowanie dodatkowych kamer (72,3\% respondentów). Wysoko lub bar- dzo wysoko przez blisko $2 / 3$ respondentów zostało ocenione wykorzystywanie w atrakcjach/obiektach turystycznych trzech innych zabezpieczeń przed atakiem terrorystycznym, a mianowicie: ogrodzeń terenu obiektu turystycznego oraz jego ochrony $(61,5 \%)$, kontroli rzeczy osobistych turystów przy wejściach do obiektu (61,2\%), a także zatrudniania policji turystycznej (61,2\%). Są to tzw. miękkie środki bezpieczeństwa, których stosowania większość turystów nawet nie zauważa lub ich nie odczuwa podczas odwiedzania obiektów turystyki kulturowej (jak np. kamery).

Warto zwrócić uwagę, że zdaniem większości respondentów żadne zabezpieczenia nie są uznawane za niepreferowane, tzn. takie, których występowanie pogarszałoby jakość wypoczynku (rys. 6).

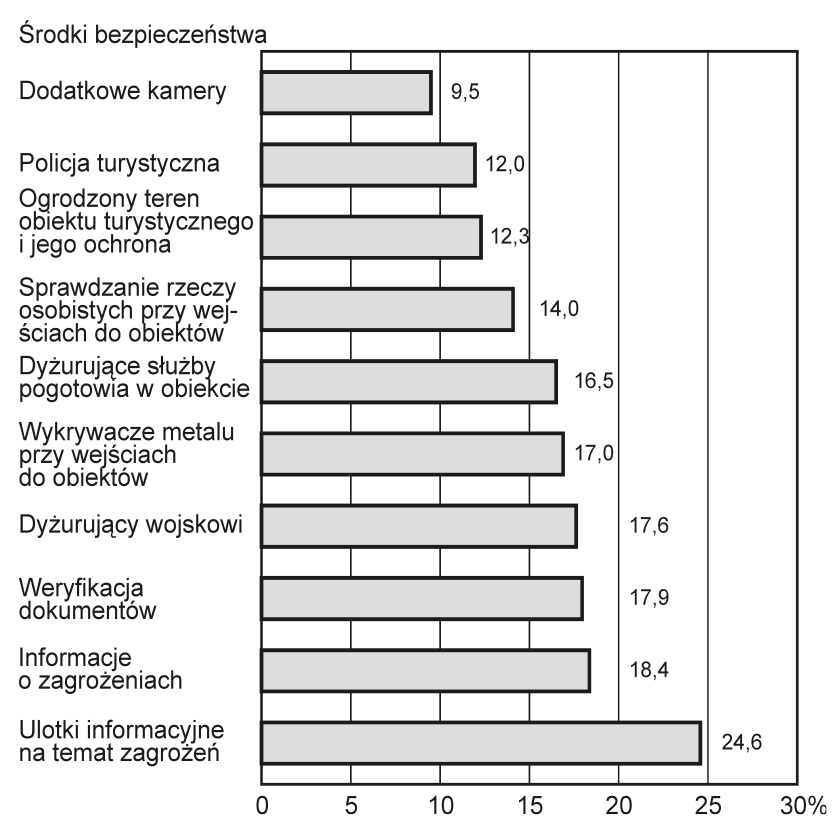

Rys. 6. Środki bezpieczeństwa w atrakcjach/obiektach tury-

stycznych, które pogarszały jakość wypoczynku litewskich respondentów (są całkowicie niepotrzebne i lub są raczej niepotrzebne, a ich obecność raczej przeszkadza)

Źródło: opracowanie własne

Spośród wymienionych w ankiecie środków bezpieczeństwa najbardziej przeszkadzałyby młodym Litwinom w zwiedzaniu obiektów turystycznych dwa: ulotki informacyjne na temat potencjalnych zagrożeń $(24,6 \%)$ oraz wiadomości informacyjne o zagrożeniach $(18,4 \%)$. Takie wybory ankietowanych informują badaczy, że wśród najbardziej "przeszkadzających" zabezpieczeń przed atakiem terrorystycznym nie ma tzw. środków twardych, co może świadczyć o tym, że respondenci są świadomi występujących zagrożeń, ale jednocześnie nie chcą być o nich informowani w trakcie odwiedzania atrakcji/ obiektów turystycznych. 


\section{PODSUMOWANIE}

Na podstawie przeglądu literatury oraz przeprowadzonych badań empirycznych możliwe jest sformułowanie następujących wniosków:

1. W dobie zwiększonego ryzyka ataków terrorystycznych turyści muszą być specjalnie chronieni i zabezpieczani, tym bardziej, że odbywają się one coraz częściej w obiektach turystyki kulturowej. Turyści w mniejszym bądź większym stopniu są świadomi występującego zagrożenia, ale nie chcą rezygnować z podróży i oczekują ochrony przed tego typu niebezpieczeństwem.

2. Nowe wyzwanie stojące przed sektorem turystycznym w postaci ochrony turystów oraz obiektów infrastruktury turystycznej przed atakami terrorystycznymi wymaga stosowania środków bezpieczeństwa. Pozostaje jednak problem sposobu wdrażania miękkich i twardych środków bezpieczeństwa, aby nie zniechęcić turystów do odwiedzania niektórych regionów turystycznych czy nie pogarszać jakości wypoczynku oraz korzystania z obiektów turystycznych.

3. W przypadku niepodjęcia środków zabezpieczających przed atakami terrorystycznymi grożą regionom turystycznym poważne konsekwencje ekonomiczne, w postaci znaczących spadków dochodów w sektorze turystycznym i transporcie, zmniejszenia zatrudnienia $\mathrm{w}$ tych sektorach, strat $\mathrm{w}$ przedsiębiorstwach kooperujących $\mathrm{z}$ nimi czy ograniczenia lub braku inwestycji $\mathrm{w}$ infrastrukturę turystyczną itd.

4. Przeprowadzone wśród młodych turystów litewskich badania ankietowe wykazały, że podróżują oni dosyć często, ale za cel podróży wybierają zazwyczaj Europę i najczęściej nie mają styczności $\mathrm{z}$ regionami zagrożonymi atakami terrorystycznymi. Ich charakterystyka ekonomiczna pokazała natomiast, że jest to grupa turystów, którzy raczej wybierają ekonomiczną bazę noclegową i gastronomiczną oraz tanie linie lotnicze.

5. Mimo że młodzi turyści litewscy są bardziej gotowi do przeżywania przygód podczas podróży, to nie są obojętni wobec zagrożeń atakami terrorystycznymi lub nie przywiązują wagi do problemu własnego bezpieczeństwa. Wyniki badań pozwalają stwierdzić, że podróżni mają przychylny stosunek do środków bezpieczeństwa stosowanych $\mathrm{w}$ infrastrukturze turystyki kulturowej i uważają je za element poprawiający jakość ich wypoczynku.

6. Podróżujący młodzi Litwini wpisują się $\mathrm{w}$ tendenję obserwowaną $w$ wielu innych krajach, prezentowaną już w literaturze, a dotyczącą większej skłonności młodych osób do podejmowania ryzyka oraz nieprzywiązywania nadmiernej wagi do tego zagadnienia. Respondenci opowiadają się częściej za tym, aby stosować miękkie środki bezpieczeństwa w obiektach/atrakcjach turystycznych, a nie twarde.

\section{BIBLIOGRAFIA}

BARTON C., HAYWOOD J., JHUNJHUNWALA P., BHATIA V., 2013, Travelling with Millennials. The Boston Consulting Group, http://www.bcg.com/documents/file129974.pdf.

BERNAŚ B., PUJER K., 2014, Bezpieczeństwo i zagrożenia w turystyce, „The Wroclaw School of Banking Research Journal”, 15, 2, s. $223-243$

BuFFA F., 2015, Young tourists and sustainability. Profiles, attitudes, and implications for destination strategies, "Sustainability", 7, s. $14042-14062$.

GARG A., 2015, Travel risks vs tourist decision making: A tourist perspective, „International Journal of Hospitality \& Tourism Systems", 8 (1), s. 1-9.

HENDERSON J.C., 2007, Tourism crises: causes, consequences and management, Elsevier, Amsterdam.

HORNER S., SWARBROOKE J., 2009, International cases in tourism management, Elsevier, Amsterdam.

How Millennials killed travel marketing as we know it, http:/ / www. mdgadvertising.com/e-books/How-Millennials-Killed-TravelMarketing/Millennial-Traveler-Ebook.pdf.

MACHADO A., 2014, How Millennials are changing travel, https:/ / www.theatlantic.com/international/archive/2014/06/howmillennials-are-changing-international-travel/373007/.

MANSFELD Y., PIZAM A., 2006, Tourism, security and safety: from theory to practice, Elsevier, Amsterdam.

MARCZAK M., 2012, Wptyw terroryzmu na rozwój turystyki międzynarodowej, „Zeszyty Naukowe Uniwersytetu Szczecińskiego. Ekonomiczne Problemy Turystyki", 4, 20, s. 89-102.

MOISĂ C.O., 2010, Aspects of the youth travel demand, „Annales Universitatis Apulensis Series Oeconomica", 12 (2), s. 575582.

MORRISON G., FERNANDES L., HAYASHI C., 2016, Millennial traveller report. Factory $\mathcal{E}$ expedia, https://www.foresightfactory. co/wp-content/uploads/2016/11/Expedia-Millennial-Travel ler-Report-Final.pdf.

MURA P., 2010, 'Scary... but i like it!' Young tourists' perceptions of fear on holiday, "Journal of Tourism and Cultural Change", 8 (1-2), s. 30-49.

PACZYŃSKA-JĘDRYCKA M., EIDER J., 2017, Turystyka w obliczu terroryzmu, „Handel Wewnętrzny”, 4 (369), s. 196-205.

red24's Global terrorism risk map 2017, https://opinion.red24. com/2017/01/10/red24s-global-terrorism-risk-map-2017/.

SANTANA G., 2005, Globalisation, safety and national security, [w:] W. Salah, C. Cooper (eds.), Tourism in the age of globalisation, Routledge, London, New York, s. 213-241.

SCHROEDER A., PENNINGTON-GRAY L., KAPLANIDOU K., ZHAN F., 2013, Destination risk perceptions among US residents for London as the Host City of the 2012 Summer Olympic Games, „Tourism Management", 38, s. 107-119. 
Survila A., MikĖNAS E., ŽUROMSKAITĖ B., 2017, The impact of terrorism on the tourism sector of Lithuania, „,Montenegrin Journal of Economics", 13, 3, s. 101-118.

TARLOW P., 2006, A social theory of terrorism and tourism, [w:] Y. Mansfeld, A. Pizam (eds.), Tourism, security and safety: from theory to practice, Elsevier, Amsterdam, s. 33-48.

TARLOW P., 2014, Reflective epilogue: concerns in tourism safety, „International Journal of Religious Tourism and Pilgrimage", 2, s. 68-70.
Travel risk and reality. The new normal for business 2016; https:// www.internationalsos.com/risk-outlook.

ŽUROMSKAITĖ B., NAGAJ R., DAČIULYTĖ R., 2018, Source of information on the perceived risk and safety in the tourism Industry, [w:] N. Grünwald, M. Zakrzewska (eds.), Series of the RobertSchmidt-Institut: Proceedings of the $5^{\text {th }}$ International Scientific Conference on "Modern Economics", University of Wismar, Wismar, s. 179-185.

Artykuł wpłyną: 27 sierpnia $2018 \mathrm{r}$.

Zaakceptowano do druku: 4 października $2018 \mathrm{r}$. 